\title{
Vibration Based NDT Methods to Verify Wood Drying Efficiency
}

\section{Nedestruktivne metode na bazi vibracija za provjeru učinkovitosti sušenja drva}

\author{
Preliminary paper • Prethodno priopćenje \\ Received-prispjelo: 20. 9. 2013. \\ Accepted-prihvaćeno: 20. 5. 2015. \\ UDK: $630 * 812.75 ; 630 * 847.23 ; 674.047 .3$ \\ doi:10.5552/drind.2015.1352
}

\begin{abstract}
The capability of application of flexural vibration test in nondestructive evaluation of wood drying was studied. Poplar timbers were conventionally kiln dried under three different drying schedules down to the final moisture content of $12 \pm 2 \%$. Dynamic Modulus of Elasticity, damping (internal friction), acoustic coefficient, and acoustic converting efficiency of each sample were evaluated using free flexural vibration test of both-ends free bars before and after the drying, while dynamic responses in each individual step were also monitored. Results revealed that emerging of some defects in the dried timber caused significant changes through the studied parameters of samples by different extents. Cracks were amongst the most prevalent defects influencing the studied factors. The desired schedule, which caused the least abundance of defects in the dried timber, was then identified using this technique. It can be stated that the existing destructive and traditional methods could be replaced by the free vibration method to evaluate the final drying quality accurately.
\end{abstract}

Key words: acoustic, defect, non-destructive-test, wood drying

SAŽETAK - U radu se ispituje mogućnost primjene vibracijskog testa savijanja pri nedestruktivnoj procjeni kvalitete sušenja drva. Drvo topole sušeno je u konvencionalnoj sušionici pri tri različita režima sušenja do konačnog sadržaja vode $12 \pm 2 \%$. Dinamički modul elastičnosti, prigušivanje (unutarnje trenje), akustični koeficijent $i$ učinkovitost akustične konverzije svakog uzorka ocijenjeni su uz pomoć vibracijskog testa slobodnog savijanja poluge, slobodne na oba kraja, prije i nakon sušenja, dok je dinamički odgovor praćen u svakom pojedinom koraku. Rezultati su pokazali da je postojanje nekih grešaka osušenog drva prouzročila znatne promjene istraživanih svojstava uzoraka u različitim omjerima. U najčešće greške osušenog drva koje utječu na ispitivana svojstva ubrajaju se pukotine. U radu je identificiran poželjni režim sušenja koji je prouzročio najmanje grešaka osušenog drva. Na temelju rezultata provedenih istraživanja može se zaključiti da je postojeće destruktivne i tradicionalne metode za procjenu kvalitete sušenja moguće zamijeniti metodom slobodnih vibracija, kojom se postiže dobra procjena konačne kvalitete sušenja.

Ključne riječi: akustika, greške drva, nedestruktivna metoda, sušenje drva

\footnotetext{
${ }^{1}$ Authors are PhD candidates at Department of Wood and Paper Science and Technology, College of Agriculture and Natural Resources, Science and Research Branch, Islamic Azad University, Tehran-Iran. ${ }^{2}$ Author is graduate student at Department of Wood Science, University of British Columbia, Vancouver, BC, Canada. ${ }^{3}$ Author is associate professor at Department of Wood and Paper Science and Technology, College of Agriculture and Natural Resources, Karaj Branch, Islamic Azad University, Karaj-Iran.

' Autori su doktorandi Odjela za znanost i tehnologiju drva i papira, Fakultet agronomije i prirodnih resursa, Islamsko sveučilište Azad, Tehran, Iran. ${ }^{2}$ Autor je student Odjela za znanost o drvu, Sveučilište British Columbia, Vancouver, BC, Kanada. ${ }^{3}$ Autor je izvanredni profesor Odjela za znanost i tehnologiju drva i papira, Fakultet agronomije i prirodnih resursa, Islamsko sveučilište Azad, Karaj, Iran.
} 


\section{INTRODUCTION}

\section{UVOD}

Nondestructive testing (NDT) techniques have recently been implemented by many researchers for quality assessment of materials or for identifying their defects (Lee, 2001; Axmon et al., 2004; Baskaran and Janawadkar, 2007; Roohnia et al., 2011a; Biechele et al., 2011). These techniques are effective means of testing and evaluating the properties of materials, which do not destroy the physical, chemical, and mechanical properties of materials and have no influence on their future performance. The exploitation and application of this technology have also been quickly developed in wood and wood-products fields for its evident advantages. Appropriate correlation between modulus of elasticity and other mechanical properties of wood (Bodig and Jayne, 1993) has encouraged researchers to engage dynamic modulus driven by nondestructive tests to estimate the mechanical properties of wood and wood products (Wang et al., 2008).

In the process of timber manufacturing, drying is the single most demanding step in terms of energy consumption and time. A reduction in drying time and/or an improvement in the quality of the dried timber offers potential economic benefits. Improvements in the wood drying process are accompanied by the better understanding of the drying process (Watanabe et al., 2008). Hence, many studies have been conducted to investigate the effect of different wood drying conditions on characteristics of the dried timber (Möttönen, 2006; Milić and Kolin, 2008; Mugabi et al., 2011; Tarmian et al., 2010; Oltean and Teischinger, 2011). All of these researches imply the importance of being aware of wood properties affected by the drying processes.

In general, destructive methods are used for quality controlling of the dried timber (Perré and Roger, 2006). In addition to being time-consuming, destructive nature of these methods makes them infeasible to be applied for the control and inspection of the entire timber. Consequently, common methods do not provide researchers and industrialists with sufficient information on properties of every individual sample. Meanwhile, some of the defects induced by wood drying schedules, such as occurrence of surface and internal cracks, which are among the most prevalent defects in wood drying processes, cannot be detected by these methods or they might be insufficient in precision.

Given the application of non-destructive tests create no change in the properties of wood, the possibility of timely evaluation of each single sample is provided. Measurement of moisture content has been investigated during drying by means of non-destructive methods (Watanabe et al., 2008; Tanaka et al., 2009; Lazarescu et al., 2010; Watanabe et al., 2012). However, the potential of the vibration-based NDT method was extended here for evaluation of the wood properties subjected to different drying conditions. Following the previous studies, this paper aims to identify the vibrational properties of drying timber influenced by different drying conditions.

\section{MATERIALS AND METHODS}

\section{MATERIJALI I METODE}

\subsection{Materials}

2.1. Materijali

Freshly-cut logs of poplar (Populus alba L.) with approximately 17-20 years of growth and 30-35 cm diameter, belonging to the Taleghan region in Iran were selected for the study. The logs were cut through the tangential direction to produce uniform timbers with a nominal thickness of $7 \mathrm{~cm}$, a length of $220 \mathrm{~cm}$, and a width of $14 \mathrm{~cm}$. Some sound samples (i.e. without any crack, knot, etc.) were selected before the drying for flexural vibration test for each schedule; 6,6 , and 5 samples for three different schedules, respectively, named $\mathrm{A}, \mathrm{B}$ and $\mathrm{C}$.

Next, their cross sections were immediately completely covered with oil paint in order to prevent moisture loss and occurrence of end cracks. A conventional semi-automatic kiln with the capacity of $3 \mathrm{~m}^{3}$ was used. Estimation of the current moisture content of kiln stacks was done by means of samples that were provided from the kiln stack and identified as control samples. From each side of the control samples, cookies for the moisture content measurement with a length of $2.5-\mathrm{cm}$ were cut and immediately weighed with an electric balance. Finally, they were oven-dried at 103 $\pm 2{ }^{\circ} \mathrm{C}$ to a constant weight

\subsection{Drying Procedure}

\subsection{Proces sušenja}

Three different moisture-based drying schedules were used, including schedule $\mathrm{A}\left(\mathrm{T}_{5}-\mathrm{D}_{2}\right.$, schedule B $\left(\mathrm{T}_{5}-\mathrm{D}_{4}\right)$, and schedule $\mathrm{C}\left(\mathrm{T}_{5}-\mathrm{D}_{6}\right)$. Drying process terminated when the final moisture content (MC) of $12 \pm 2$ $\%$ was reached. To introduce the new conditions in the kiln, the control samples, depending on the drying rate, were weighed at least once a day. This change was made based on the average MC of the wettest half of the control samples (Simpson, 1991). Finally, the drying process was terminated without any conditioning treatment for all of the drying runs.

\subsection{Flexural Vibration Procedure}

2.3. Vibracijski test savijanja

The cut samples were maintained in the open air for 2 days prior to drying. Then, flexural vibration in free-free bar test was conducted on wet specimens in order to have primary information for further investigations of the acoustic properties of the dried timber (Fig. 1). This test was also carried out immediately after completion of drying process.

Based on Timoshenko's improved theory of flexural free vibration test, as described in the literature (Bordonné, 1989; Brancheriau and Baillères, 2002; Roohnia et al. 2011a, b), after obtaining the $\mathrm{n}^{\text {th }}$ modal frequency through Fast Fourier Transform (FFT), based on coordinates of evaluated spots from at least three initial modes of vibration, longitudinal specific modulus of elasticity was determined through a linear regression (Equation 1). 


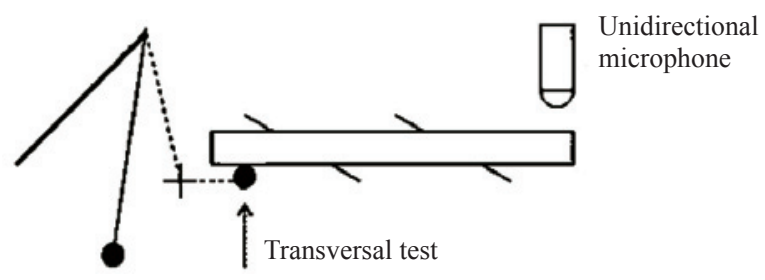

Figure 1 Experimental setup of flexural (transversal) free vibration test (Brancheriau et al., 2010; Roohnia et al., 2012)

Slika 1. Provedba slobodnoga vibracijskog testa savijanja (poprečno) (Brancheriau et al., 2010.; Roohnia et al., 2012.)

$$
a_{n}=\left(\frac{E}{\rho}\right)-\left(\frac{E}{K \times G_{i j}}\right) \cdot b_{n}, R^{2} \leq 1
$$

where the intercept $(E / \rho)$ is flexural specific modulus of elasticity, $G_{i j}$ is shear modulus in LR or LT plane (not followed in present approach), $K$ is shape coefficient, equivalent to 0.833 (Brancheriau and Baillères, 2002), $a_{n}$ and $b_{n}$ are the coordinates of the evaluated spots from at least three initial modes of flexural vibration, $\mathrm{n}$ corresponds to mode number and $R$ is the correlation coefficient of the Timoshenko's linear trend. The origin and background to the derivation of the Equation (1) were presented in details in the above introduced group of literature. NDT-lab ${ }^{\circledR}$ Portable System Setup for flexural free vibration test developed using MATLAB ${ }^{\circledR} 7.1$ (Roohnia et al., 2006; Roohnia, 2007) was used here to obtain Fast Fourier Transform and related vibrational parameters (Fig. 1).

Damping due to internal friction ( $\tan \delta)$ was calculated from logarithmic decrement (Bodig and Jayne, 1993; Brémaud, 2008).

Acoustic coefficient $(K)$ and acoustical converting efficiency $(A C E)$ were calculated based on modulus of elasticity, density, and damping factor using Equations 2 and 3:

$$
\begin{gathered}
K=\sqrt{\frac{E}{\rho^{3}}} \\
A C E=\frac{K}{\tan \delta}
\end{gathered}
$$

Where, $K$ is the acoustic coefficient $\left(\mathrm{m}^{4} \cdot \mathrm{s}^{-1} \cdot \mathrm{kg}^{-1}\right)$, $E$ is the modulus of elasticity $(\mathrm{Pa}), \rho$ is the density of wooden specimens $\left(\mathrm{kg} \cdot \mathrm{m}^{-3}\right), A C E$ is the acoustical converting efficiency $\left(\mathrm{m}^{4} \cdot \mathrm{s}^{-1} \cdot \mathrm{kg}^{-1}\right)$.

The recording rate for the audio files was adjusted to $44100 \mathrm{~Hz}$ with 16 bits encoded (bit depth).

The scatter plots were used to compare the acoustical properties and their related change patterns.

\section{RESULTS AND DISCUSSION}

3. REZULTATI I RASPRAVA

It seems critical to have an idea about the acoustic coefficient and acoustical converting efficiency. Acoustic coefficient $(K)$ is an indicative of the proportion of elasticity of wood to its density, and in combination with damping due to internal friction is crucial in computing acoustic converting efficiency $(A C E)$. Either of factors ( $K$ or $A C E$ ) were applied as a criterion in selection of woods used in musical instrument industry and it is highly believed that as much the rate of these two factors in wood is higher, that wood will be more appropriate for the musical instrument industry (Roohnia et al., 2011b; Rujinirun et al., 2005). This phenomenon would surely benefit from a better quality of wood with lower amounts of defects.

Drying-induced cracks were of the most important and major defects during the wood drying processes. They increase the internal friction, which consequently leads to the increase of the damping factor in the wood. In fact, as much the damping factor is lower and the acoustic coefficient is higher, the wood would have better resonance properties. Therefore, by considering the acoustic coefficient combined with damping in the shape of acoustical converting efficiency $(A C E)$, the impact of defects for investigating the wood drying efficiency seems to become more and more facilitated.

Fig. 2 denotes that all the three drying schedules led to an increase in dynamic modulus of samples after the drying process, and schedule A resulted in a higher increase than the others, however, a lower correlation coefficient was observed.

The effect of each schedule on damping factor is shown in Fig. 3. Drying schedules of B and C led to an increase in damping factor, which was higher in the latter one. Conversely, schedule A, unlike B and C, decreased the damping factor. As the final moisture content was the same for all the schedules, it might inspire the preferences of schedule A.

Fig. 4 shows that the acoustic coefficient of samples dried under all the three schedules has been higher than the corresponding figure before the drying process. Schedule A experienced a higher increase than schedules $\mathrm{C}$ and $\mathrm{B}$, respectively. All the three drying schedules led to an increase in acoustic converting efficiency in samples and the rate of increase in schedule A was higher than in schedule B and C, respectively (Fig. 5). It can be observed that not only the samples applied in this test showed unequal dynamic response, but the rate of these changes was also different depending on the schedule applied.

All the three drying schedules led to an increase in Dynamic Modulus of Elasticity of dried timber as against the non-dried ones, which can be attributed to mass reduction of samples due to moisture loss during the drying process (equation 1). In addition, dynamic modulus of samples dried by schedule A showed a higher increase than those dried by the schedule $\mathrm{C}$ and $\mathrm{B}$, respectively. Although, changes in dynamic modulus are considered as one of the most important factors in qualitative evaluation of wood products, it should be born in mind that the place of defects, especially cracks, on wooden bars is highly effective on dynamic modulus of elasticity. Hence, we could not just rely on changes of this factor for judging and distinguishing the schedules applied.

In addition to the role of defects on damping factor, wood species (density, extractive contents, wood 


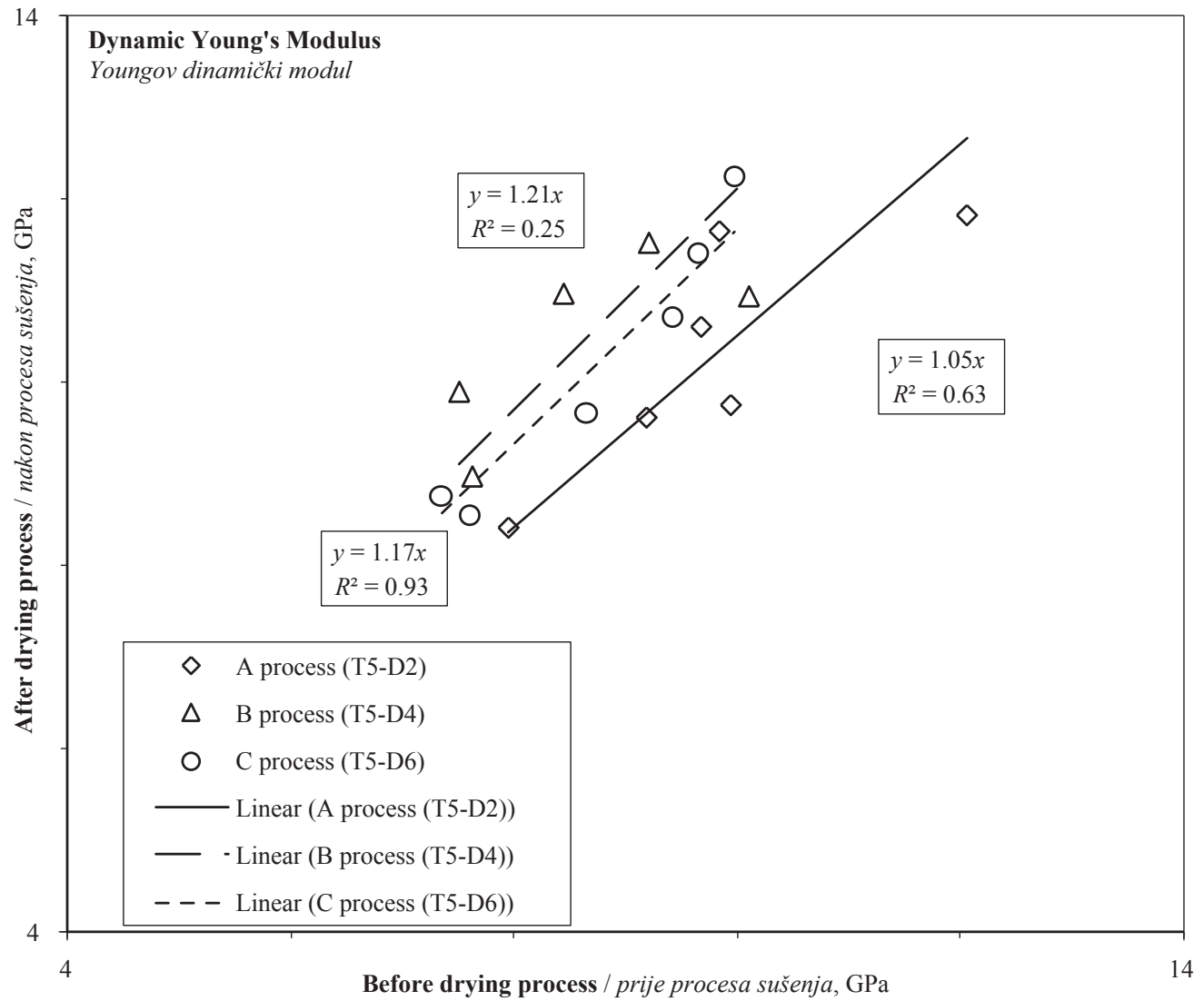

Figure 2 Effect of drying schedule on Dynamic Modulus of Elasticity

Slika 2. Utjecaj režima sušenja na dinamički modul elastičnosti

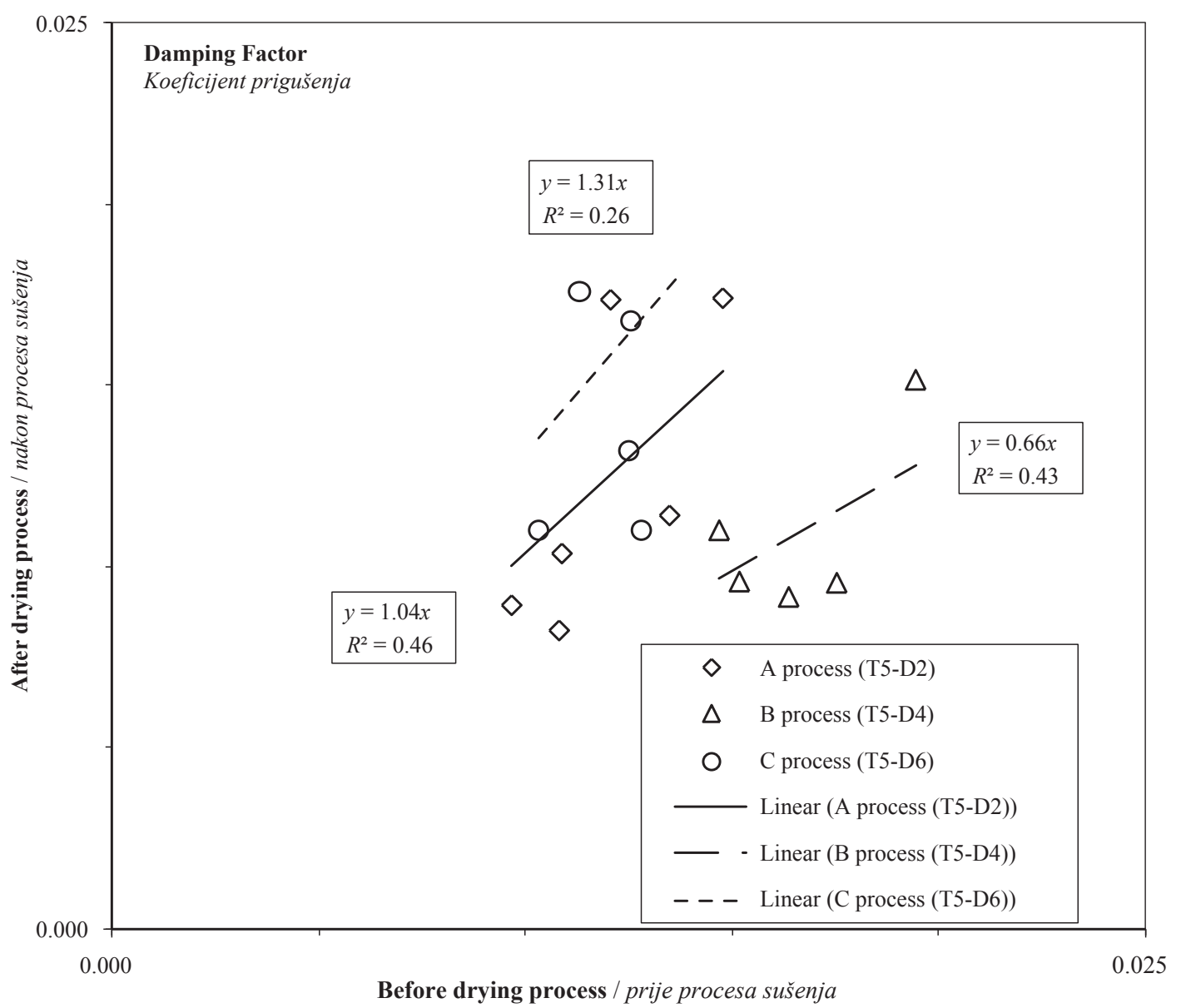

Figure 3 Effect of drying schedule on damping factor

Slika 3. Utjecaj režima sušenja na koeficijent prigušenja 


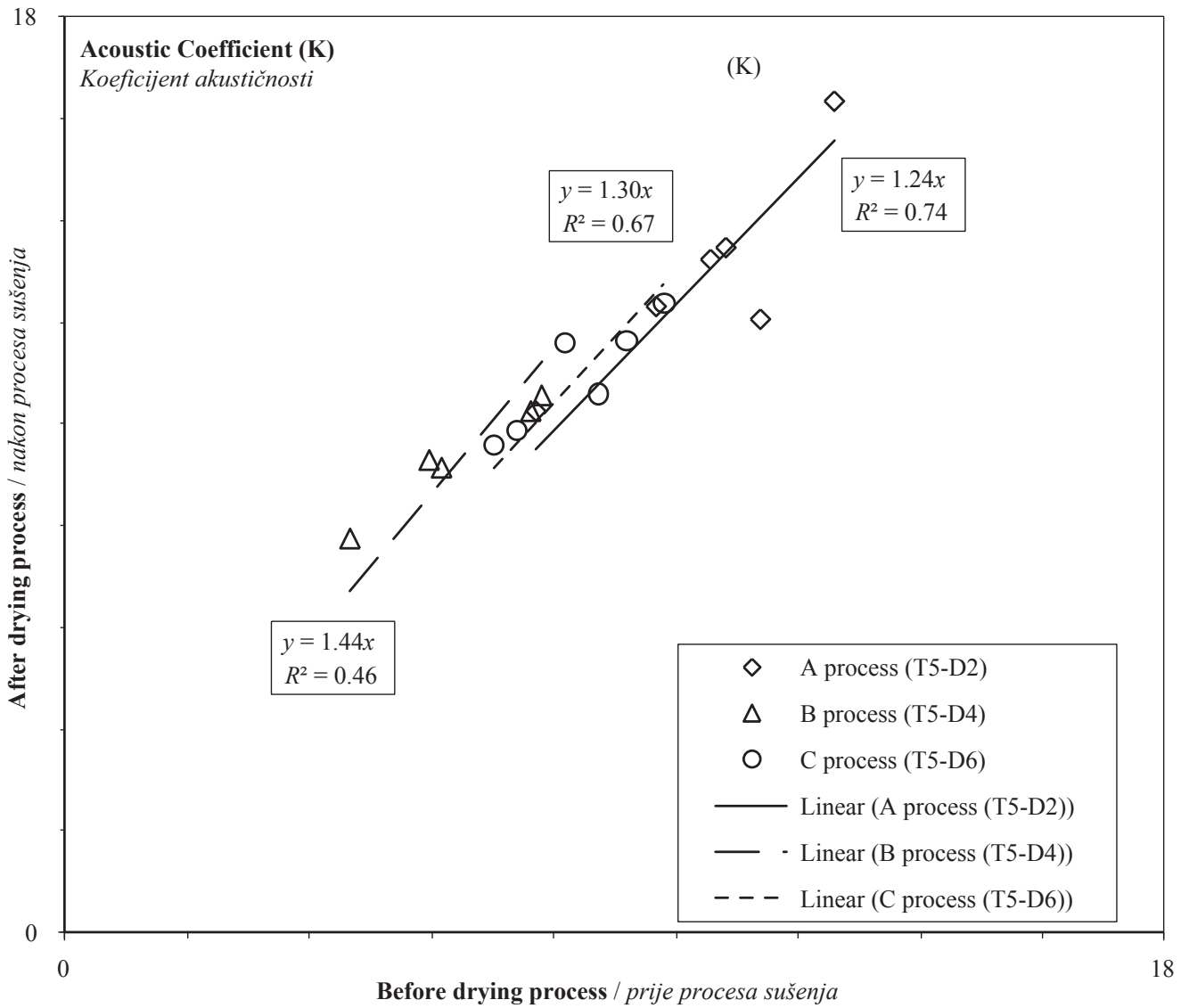

Figure 4 Effect of drying schedule on acoustic coefficient $\left(\mathrm{m}^{4} \cdot \mathrm{s}^{-1} \cdot \mathrm{kg}^{-1}\right)$

Slika 4. Utjecaj režima sušenja na akustični koeficijent $\left(\mathrm{m}^{4} \cdot \mathrm{s}^{-1} \cdot \mathrm{kg}^{-1}\right)$

texture, etc.) and moisture content are also influential (Tsoumis 1991). By reducing the moisture content of samples, the damping factor is expected to be reduced in the dried samples. However, this only happened in schedule A; and in the other two schedules (B and C) this factor increased and its rate was higher in schedule $\mathrm{C}$ than in schedule B. In this regard, existence of cracks in wood could be considered as a culprit in increasing of damping factor (Ouis, 2004; Roohnia et al., 2010; Hossein et al., 2009; Roohnia et al., 2011a). Therefore, the reduction in damping factor in schedule $\mathrm{A}$, unlike the other two schedules, can be attributed to less formation of defects. In the preliminary stage of the pre- sent research, Shahverdi et al. (2012) reported a table, which has been extended (Table 1), to demonstrate the amount of visually recognized cracks attributed to the drying schedules A, B and C.

The rate of internal defect propagation due to drying processes severity has been higher in schedules $\mathrm{B}$ and $\mathrm{C}$ than in schedule $\mathrm{A}$. In addition, considering total crack lengths and their abundance, schedule A has resulted in smaller amounts of drying defects i.e. crack (Table 1).

As mentioned before, acoustic coefficient is one of the most important parameters in estimating the acoustic specifications of a material, which is only in-

Table 1 Intensity of internal cracks in dried timber under three schedules

Tablica 1. Intenzitet unutarnjih pukotina u uzorcima drva sušenim pri tri različita režima sušenja

\begin{tabular}{|l|c|c|c|}
\hline $\begin{array}{l}\text { Crack length } \\
\text { Duljina pukotine }(\mathrm{mm})\end{array}$ & $\begin{array}{c}\text { Abundance in schedule A } \\
\text { Broj pukotina pri režimu } \\
\text { sušenja A }\end{array}$ & $\begin{array}{c}\text { Abundance in schedule B } \\
\text { Broj pukotina pri režimu } \\
\text { sušenja B }\end{array}$ & $\begin{array}{c}\text { Abundance in schedule C } \\
\text { Broj pukotina pri režimu } \\
\text { sušenja C }\end{array}$ \\
\hline $1-10$ & 7 & 76 & 40 \\
$11-20$ & 8 & 47 & 24 \\
$21-30$ & 4 & 6 & 18 \\
$31-40$ & 6 & 3 & 14 \\
$41-50$ & 0 & 0 & 8 \\
$51-60$ & 0 & 0 & 2 \\
$61-70$ & 0 & 0 & 108 \\
\hline Total abundance & 25 & 132 & 1668 \\
Ukupan broj & 365 & 812 & \\
\hline Total Crack Length* & & & \\
Ukupna duljina pukotina & & & \\
\hline
\end{tabular}

*A summation based on the minimum value in crack length ranges. / Zbroj se temelji na najmanjoj vrijednosti iz raspona duljine pukotine. 


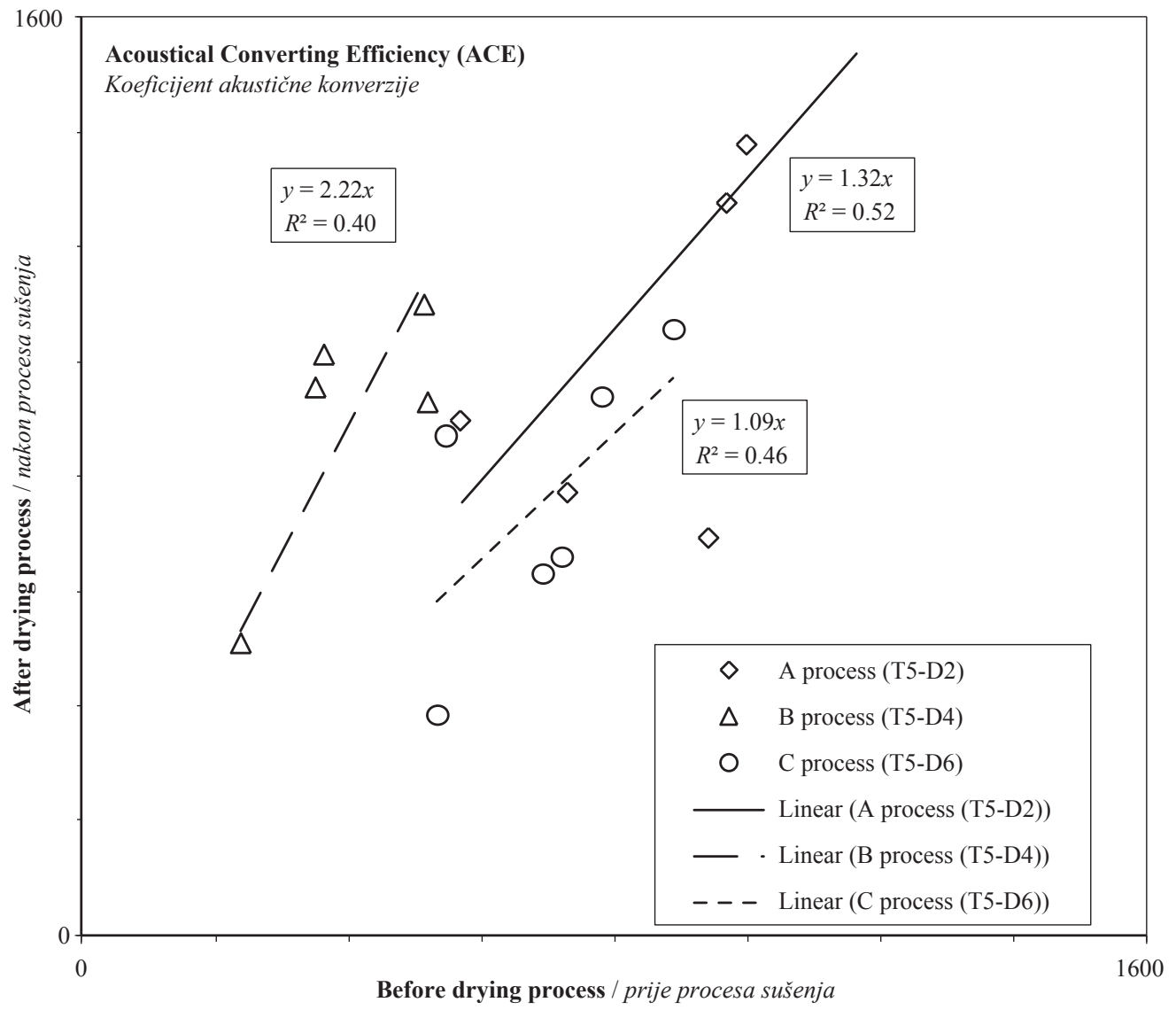

Figure 5 Effect of drying schedule on acoustical converting efficiency

Slika 5. Utjecaj režima sušenja na koeficijent akustične konverzije

fluenced by modulus of elasticity and density. Therefore, observing a trend like that observed in modulus of elasticity has not been a sufficient criterion. By considering the explanations expressed about modulus of elasticity, the changes that occurred in this factor cannot be solely a basis for judgment between the drying schedules used. Especially not in case when the trend R squares were not sufficiently high. Though, this correlation was strengthened in $A C E$ comparisons.

As shown in equation 2, there is a direct relationship between acoustic coefficient and dynamic modulus of elasticity and, on the other hand, the same relationship can be found between dynamic modulus of elasticity and mechanical properties of wood. Since acoustic converting efficiency is a proportion of acoustic coefficient to damping factor (equation 5) and damping factor itself might be under the influence of cracks, it can be predicted that acoustic converting efficiency would be a proportion of wood resistance to the extent of defects induced by the drying process. The amount of this factor in the wood dried by schedule A was over twice as much as the non-dried one; whereas, in the wood dried by schedules B and C, this amount showed a 32 and $9 \%$ increase, respectively.

The increasing trend of acoustic converting efficiency in the dried timber as opposed to non-dried one in all the three drying schedules was predictable due to a reduction of MC during drying followed by the reduction of damping factor. However, the increasing rate of this factor indicates that each schedule was ap- plied to the extent to which secondary defects could be caused in timber. Hence, schedule A caused the least abundance of cracks in the dried samples as against schedule $\mathrm{B}$ and $\mathrm{C}$, respectively.

It could be concluded that the free vibration method has the potential to substitute the existing destructive and traditional methods in qualitative nondestructive grading of dried timber, especially in determining the effect of the drying schedule on the development of cracks as the most common defect in the drying processes. Meanwhile, the acoustical converting efficiency $(A C E)$, which is used as a criterion for wood quality in musical instrument industry, can be introduced as one of the key factors in grading of the dried timber under different drying conditions. A visual or destructive traditional inspection of wood drying quality may neglect hidden defects, unlike the proposed non-destructive evaluation.

\section{CONCLUSIONS}

\section{ZAKLJUČAK}

This research evaluated the potential of the vibration-based non-destructive testing method of timber influenced by the wood drying process. Different dynamic responses of samples before and after each drying schedule provided the ability to determine the importance of either internal or external defects in wood.

1) The least amount of cracks was observed in the samples dried by the schedule $\mathrm{A}\left(\mathrm{T}_{5}-\mathrm{D}_{2}\right)$, in com- 
parison to the schedules $\mathrm{B}\left(\mathrm{T}_{5}-\mathrm{D}_{4}\right)$ and $\mathrm{C}\left(\mathrm{T}_{5}-\mathrm{D}_{6}\right)$, respectively. In other words, non-destructive testing methods are capable of being used in sorting strategies of timber as they are more and more sensitive in detecting the defects.

2) There was a significant difference between samples concerning the dynamic modulus of elasticity, damping factor, acoustic coefficient, and acoustic converting efficiency before and after the drying process.

3) Dynamic modulus of elasticity and acoustic coefficient may not be exclusively sufficient for choosing between the drying schedules applied.

4) Considering the negative impact of cracks on damping factor and acoustic coefficient, it was shown that changes in acoustic converting efficiency could be considered as an effective way for evaluating the drying schedules.

\section{REFERENCES}

\section{LITERATURA}

1. Axmon, J.; Hansson, M.; Sornmo, L., 2004: Experimental study on the possibility of detecting internal decay in standing Picea abies by blind impact response analysis. Forestry, 77 (3): 179-192.

http://dx.doi.org/10.1093/forestry/77.3.179

2. Baskaran, R.; Janawadkar, M. P., 2007: Imaging defects with reduced space inversion of magnetic flux leakage fields. NDT\&E International, 40: 451-454.

http://dx.doi.org/10.1016/j.ndteint.2007.01.002

3. Biechele, T.; Chui, Y. H.; Gong, M., 2011: Comparison of NDE techniques for assessing mechanical properties of unjointed and finger-jointed lumber. Holzforschung, 65: 397-401. http://dx.doi.org/10.1515/hf.2011.038

4. Bodig, J.; Jayne, B., 1993: Mechanics of wood and wood composites (Persian translation by Ebrahimi. Gh.). Tehran University press. $686 \mathrm{pp}$.

5. Bordonné, P. A., 1989: Module dynamique et frottement intérieur dans le bois: Mesures sur poutres flottantes en vibrations naturelles. Thèse de doctorat de l'INP de Lorraine soutenue à Nancy, $154 \mathrm{p}$.

6. Brancheriau, L.; Baillères, H., 2002: Natural vibration analysis of clear wooden beams:a theoretical review. Wood Science and Technology, 36: 347-365. http://dx.doi.org/10.1007/s00226-002-0143-7

7. Brancheriau, L.; Kouchade, C.; Bremaud, I., 2010: Internal friction measurement of tropical species by various acoustic methods. J. Wood Sci., 56 (5): 371-379. http://dx.doi.org/10.1007/s10086-010-1111-8

8. Bremaud, I., 2008: Caracterisation mecanique des bois et facture: origins et recensement de la variabilite. Acte de la Journee d'etude Le bois: Instrument du Patrimoine Musical - Cite de la Musique, 24-46.

9. Hossein, M. A.; Roohnia, M.; Shahverdi, M., 2009: Some footprints of wood internal defects on three first mode-shapes of free vibration 16 th international symposium on nondestructive testing and evaluation of wood. Beiging, China.

10. Lazarescu, C.; Watanabe, K.; Avramidis, S., 2010: Density and Moisture Profile Evolution during Timber Drying by CT Scanning Measurements. Drying Technology, 28: 460-467. http://dx.doi.org/10.1080/07373931003613478

11. Lee, S. J., 2001: Free-vibration analysis of plates and sheels with a nine-node assumed natural degenerated shell element. Journal of Sound and vibration. 241 (4): 605-633. http://dx.doi.org/10.1006/jsvi.2000.3313

12. Milić, G.; Kolin, B., 2008: Influence of Duration of the Conditioning Process on the Reduction of Case-Hardening Level in Kiln-Dried Beech and Oak lumber. Drying Technology, 26: 1225-1231. http://dx.doi.org/10.1080/07373930802307035

13. Möttönen, V., 2006: Variation in Drying Behavior and Final Moisture Content of Wood during Conventional Low Temperature Drying and Vacuum Drying of Betula pendula Timber. Drying Technology, 24: 1405-1413. http://dx.doi.org/10.1080/07373930600952750

14. Mugabi, P.; Rypstra, T.; Vermaas, H. F.; Nel, D. G., 2011: Effect of kiln drying schedule on the quality of South African grown Eucalyptus grandis poles. Eur. J. Wood Prod., 69: 19-26. http://dx.doi.org/10.1007/s00107-009-0392-3

15. Oltean, L.; Teischinger, A., 2011: Influence of low and moderate temperature kiln drying schedules on specific mechanical properties of Norway spruce wood. Eur. J. Wood Prod., 69: 451-457. http://dx.doi.org/10.1007/s00107-010-0467-1

16. Ouis, D., 2004: Assessment of severity and localization of a transversal crack in a wood beam through a study of its natural modes of vibration. Holz Roh Werkst, 62: 1722. http://dx.doi.org/10.1007/s00107-003-0442-1

17. Perré, P.; Roger, B. K., 2006: Drying of Wood: Principles and Practices. Text book, $57 \mathrm{p}$.

18. Roohnia, M.; Bremaud, I.; Guibal, D.; Manouchehri, N., 2006: NDT-LAB; Software to evaluate the mechanical properties of wood. In: M. Fioravanti and N. Macchioni: International Conference on Integrated Approach to Wood Structure Behaviour and Applications - Joint meeting of ESWM and Cost Action E35. 15-17 May, Florence - Italy, DISTAF - University of Florence, 213218.

19. Roohnia, M., 2007: NDT-LAB, System to evaluate the mechanical properties of wood. IR-Patent No. 44032/2208-1386. Iranian official Journal.

20. Roohnia, M.; Yavari, A.; Tajdini, A., 2010: Elastic Parameters of Poplar Wood with End-Cracks. Annals of Forest Science, 67 (4): 1-6. http://dx.doi.org/10.1051/forest/2009129

21. Roohnia, M.; Alavi-Tabar, S. E.; Hossein, M. A.; Brancheriau, L.; Tajdini, A., 2011a: Dynamic modulus of elasticity of drilled wooden beams. Nondestructive Testing and Evaluation, 26 (2): 141-153. http://dx.doi.org/10.1080/10589759.2010.533175

22. Roohnia, M.; Tajdini, A.; Manouchehri, N., 2011b: Assessing wood in sounding boards considering the ratio of acoustical anisotropy. NDT\&E International, 44: 13-20. http://dx.doi.org/10.1016/j.ndteint.2010.09.001

23. Roohnia, M.; Kohantorabi, M.; Jahan-Latibari, A.; Tajdini, A.; Ghaznavi, M., 2012: Nondestructive assessment of glued joints in timbers applying vibration-based methods. Eur. J. Wood Prod., 70 (6): 791-799. http://dx.doi.org/10.1007/s00107-012-0616-9

24. Rujinirun, C.; Phinyocheep, P.; Prachyabrued, W.; Laemsak, N., 2005: Chemical treatment of wood for musical instruments. Part I: acoustically important properties of wood for the Ranad (Thai traditional xylophone. Wood Science and Technology, 39: 77-85. http://dx.doi.org/10.1007/s00226-004-0275-z

25. Shahverdi, M.; Dashti, H.; Hossein, M. A., 2012: Establishing a kiln drying schedule for poplar (Populus alba L.) lumber of $7 \mathrm{~cm}$ thickness. BioResources, 7 (1): 26-37.

26. Simpson, W. T., 1991: Dry Kiln Operator's Manual. USDA Forest Service. Agriculture Handbook. 188 p. 
27. Tanaka, T.; Avramidis, S.; Shida, S., 2009: Evaluation of moisture content distribution in wood by soft X-ray imaging. J Wood Sci, 55: 69-73. http://dx.doi.org/10.1007/s10086-008-0997-x

28. Tarmian, A.; Eshagh, S.; Gholamiyan, H., 2010: The contradictory effect of drying internal checks and moisture changes on the ultrasonic propagation in poplar wood (Populous nigra). J Indian Acad Wood Sci, 7 (1-2): $43-$ 48. http://dx.doi.org/10.1007/s13196-011-0009-4

29. Tsoumis, G., 1991: Science and technology of wood. Van Nostrand Reinold.

30. Wang, S.; Chen, J.; Tsai, M.; Lin, C.; Yang, T., 2008: Grading of Softwood Lumber Using Non-destructive Techniques. Journal of Material Processing Technology, 208: 149-158.

http://dx.doi.org/10.1016/j.jmatprotec.2007.12.105

31. Watanabe, K.; Saito, Y.; Avramidis, S.; Shida, S., 2008: Non-destructive Measurement of Moisture Distribution in Wood during Drying Using Digital X-ray Microscopy. Drying Technology, 26 (5): 590-595. http://dx.doi.org/10.1080/07373930801944796
32. Watanabe, K.; Lazarescu, C.; Shida, S.; Avramidis, S., 2012: A Novel Method of Measuring Moisture Content Distribution in Timber during Drying Using CT Scanning and Image Processing Techniques. Drying Technology, 30: 256-262.

http://dx.doi.org/10.1080/07373937.2011.634977

\section{Corresponding address:}

Assoc. Prof. MEHRAN ROOHNIA, Ph.D.

Karaj Branch, Islamic Azad University

Shahid Moazen BLVD.

Rajaee-shahr, KARAJ - IRAN

e-mail: mehran.roohnia@kiau.ac.ir 